\title{
EXISTING ACCOMMODATION CAPACITY, FACTOR OF INFLUENCE ON TOURIST ARRIVALS. CASE STUDY: CALARASI COUNTY, ROMANIA
}

\author{
Cosmin-Nicolae Mirea \\ Puiu Nistoreanu
}

https://doi.org//10.20867/tosee.06.31

\begin{abstract}
Purpose - The existence of accommodation capacity is an indispensable condition for carrying out tourist activities. Therefore, the purpose of this research is to find out the influence of accommodation capacity on the number of tourists, the number of overnight stays and the average stay, so as to highlight the importance of this indicator for the tourist potential of Calarasi County. Methodology - In order to analyze the influence of the existing accommodation capacity on the number of tourists, the number of overnight stays and the average stay, the simple regression model was used, so as to find out what percentage of the dependent variables is explained by the dependent variable. The Eviews program was used to create the simple regression model.

Findings - Following the application of regression, we found out that in Calarasi County, $30 \%$ of the variation in the number of tourists is explained by the variation in existing accommodation capacity. There is also a weak link between existing accommodation capacity and the number of nights spent.

Contribution - The present study focused on the influence of accommodation capacity on some indicators of tourist traffic, and the results could meet the decisions that local authorities could take regarding the support of accommodation units in the county

Keywords: existing accommodation capacity, number of tourists, Calarasi county, regression,
\end{abstract} correlation coefficient, Romania.

\section{INTRODUCTION}

Being an economic activity, tourism is dependent on a specific material base through which tourist activities are carried out and tourist services are provided. In other words, tourist services cannot be provided without a specific technical-material basis. Based on this consideration, the accommodation structures and implicitly the accommodation spaces justify their importance in the tourism field. According to Milea, Pascu and Nedea (2013, 391), "accommodation units are the most important component of the material base of tourism". Thus, we can consider that the existence of accommodation is a minimum criterion for carrying out tourist activities, insofar as the existence of accommodation can contribute to capitalizing on the tourist potential of a certain area.

In this sense, in the context of the existence of tourist attractions, the lack of tourists can be generated by the non-existence of accommodation structures. Moreover, some studies have shown that other commercial units tend to be located around accommodation structures, such as restaurants, gift shops or nightclubs (Anguera-Torrell and Cerdan 2021). More precisely, tourists can be attracted through the accommodation structures. 
ToSEE - Tourism in Southern and Eastern Europe, Vol. 6, pp. 467-478, 2021.

C-N. Mirea, P. Nistoreanu: EXISTING ACCOMMODATION CAPACITY, FACTOR OF INFLUENCE ...

Based on this fact, it can also contribute to the development of other economic sectors, because "the need for labor and the production of goods and services are stimulated" (Minciu 2004, 304) to respond the needs of tourists. In other words, the existence of accommodation structures contributes to the economic growth of tourist destinations. Due to the fact that the existing accommodation capacity is a ,macroeconomic indicator of tourism characterization" (Cristache 2008, 64) with important economic effects on tourist destinations, the analysis of its influence on indicators of tourist traffic is completely justified. The main component parts of this research are the literature review, the description of the research methodology, the results obtained and the conclusions.

\section{LITERATURE REVIEW}

\subsection{General features on accommodation capacity}

The tourist market, like any other economic market, is defined by the existence of supply and demand. If the tourist demand is limited to the number of tourists and their preferences, the tourist offer is defined by a much wider spectrum, because the components are numerous and diverse. Thus, the tourist offer can be seen as the sum of the following elements: tourist potential, tourism specific infrastructure, tourism employees and tourist services (Minciu 2004, 151). In this sense, the existing accommodation capacity, expressed through accommodation places, is part of the tourist offer, especially of the tourism specific infrastructure. According to Pop et al. (2020, 552 ), accommodation capacity or rather, accommodation units are part of the tourist heritage. Moreover, the existing accommodation capacity is defined as follows: "represents the number of accommodation places, registred in the last act of reception and classification of an accommodation unit" (Cristache 2008, 64).

Some studies have shown that tourist accommodation capacity can be influenced by other indicators of specific tourist infrastructure, for example, accommodation capacity in mountain resorts can be influenced by the number of kilometers of slopes or the number of cable transport equipment (Skoric 2012, 1361). Also, regarding the accommodation capacity there are two perspectives, namely the desideratum of the tourist and the desideratum of the owner of the accommodation unit. More precisely, the tourist wants to have accommodation capacities in the area he wants to visit and the owner of the accommodation unit wants to use as much as possible of his accommodation capacity. A big problem turns out to be the imbalance between the two desideratum. Thus, forecasting tourist demand and the need for accommodation can be an effective method in eliminating the imbalance between the demand for accommodation and the supply of accommodation (Petrevska 2012, 91). It should be emphasized that the existence of accommodation capacity in a certain tourist area is the fundamental basis for meeting the tourist demand with the tourist offer, especially since the accommodation service, the transport service, the food service and the leisure service are the basic components of the package of tourist services.

Also, the accommodation capacities must meet all the needs of tourists, otherwise, as shown by Medina-Munoz, Medina-Munoz and Sanchez-Medina (2016, 133), the existing accommodation capacities must be renovated in accordance with the needs of 
ToSEE - Tourism in Southern and Eastern Europe, Vol. 6, pp. 467-478, 2021.

C-N. Mirea, P. Nistoreanu: EXISTING ACCOMMODATION CAPACITY, FACTOR OF INFLUENCE ...

tourists. Thus, in terms of tourist satisfaction, it seems that accommodation structures have a fairly large influence. At the same time, the importance of the accommodation capacity results from the fact that its size reveals how developed is the tourist offer in a certain area. Moreover, as mentioned by Lakicevic and Sagic $(2019,87)$, in many cases, a major problem of tourist destinations is the management of tourist infrastructure, including accommodation capacity and the creation of new tourist facilities. According to another perspective, accommodation capacity can also be used as an indicator to measure overtourism (Cruz and Zaragoza 2019), in the sense that a high occupancy rate means the presence of a large number of tourists in the same place and at the same time, which leads to the agglomeration of the tourist destination. In Romania, the existing accommodation capacity is one of the indicators of territorial sustainable development, being the only indicator analyzed of this type in the field of tourism (National Institute of Statistics 2018). In this sense, it can be admitted that the indicator of tourist accommodation capacity is a variable, flexible and complex one, being a key element in the development of tourist activities. As shown by Țigu, Călărețu and Bulin (2013), the variability of this indicator may also be due to the effects that certain national strategies have on tourism or due to the area where the accommodation structures are located, as they may be located in mountainous areas, in costal areas, in spa areas.

Accommodation capacity was the subject of research for other authors, who analyzed the evolution of accommodation capacity in a county in Romania (Maican, Cordos, Pastiu and Muntean 2014) or in the development regions of Romania (Nicula and Neagu 2013; Sava 2013). Our study is not based on the analysis of the evolution of accommodation capacity, but on its influence on some indicators of tourist traffic. Other authors (Gheorghe 2015) showed that there is a direct link between the number of overnight stays, as an independent variable and the accommodation capacity in operation, as a dependent variable, in a given period of time or that there is a strong influence of tourist arrivals on variation in accommodation capacity (Bawa 2017, 17). Most studies are based on the analysis in structure and dynamics of the existing accommodation capacity and less on the analysis of the influence and correlation between this indicator and other variables.

\subsection{Calarasi County, Romania}

Over time, Romania has gone through several phases in terms of territorial administrative organization, due to different governments that have succeeded over the years. Currently, Romania consists of 41 counties and the capital Bucharest (Săgeată 2013, 16). Thus, one of the 41 counties is Calarasi County. Calarasi County has the following coordinates: it is located in southeastern of Romania and borders the counties of Ialomita in the north, Constanta in the east, Giurgiu in the west, Ilfov in the northwest, while in the south it is bordered by the Danube River and Bulgaria (Mărculeț 2019, 33). According to the National Institute of Statistics (http://statistici.insse.ro/shop/ accessed February 5 2021), at the level of 2020, the population of the county was 280252 people, and the distribution by residence was as follows: 102124 people lived in urban areas and 178128 people lived in rural areas. Thus, approximately $64 \%$ of the county's population lives in rural areas, which gives the county a predominantly rural character. This is due to the fact that on the territory of the county there are two municipalities (Calarasi and Oltenita), three cities 
ToSEE - Tourism in Southern and Eastern Europe, Vol. 6, pp. 467-478, 2021.

C-N. Mirea, P. Nistoreanu: EXISTING ACCOMMODATION CAPACITY, FACTOR OF INFLUENCE ...

(Budesti, Fundulea, Lehliu-Gara) and 50 communes (National Institute of Statistics http://statistici.insse.ro/shop/ accessed February 5, 2021).

From a touristic point of view, Calarasi County is endowed with both natural tourist objectives: Borcea Branch of the Danube, Mostistea Valley, Ciocanesti Island, Ciornuleasa Forest, Sarulesti Lake, Galatui Lake, Potcoava Lake etc; as well as with anthropic tourist objectives: Lower Danube Museum from Calarasi municipality, Plataresti Monastery, Negoiesti Monastery, Prefecture Palace from Calarasi municipality etc (Calarasi County Council https://www.calarasi.ro/index.php/judetul- calarasi-meniustanga/turism accessed February 22 2021). A big problem of Calarasi County is related to the capitalization of tourist objectives and the fact that the county is visited by a relatively small number of tourists compared to its tourist potential. Thus, we want to find out if the accommodation capacity is an impediment in terms of attracting tourists in Calarasi County.

\section{RESEARCH METHODOLOGY}

The present study has as object of research the influence that the existing accommodation capacity has on some indicators of the tourist traffic, more precisely the number of tourists, the number of overnight stays and the average stay, the research question being "What is the influence of the existing accommodation capacity on the number of tourists, the number of overnight stays and the average stay in Calarasi County?". The premise from which the research starts is the fact that the specific tourist infrastructure is a strong factor influencing the indicators of the tourist traffic. The research area is represented by Calarasi County in Romania.

For the research, data were collected from the website of the National Institute of Statistics, in the period 2000-2019, and the research method used was simple regression. Thus, through simple regression we aimed to create regression models between the existing accommodation capacity as an independent variable and the indicators of tourist traffic (number of tourists, number of overnight stays, average stay) as dependent variables in order to find the influence of independent variable on dependent variables. The Eviews program used to process the data. The data series taken from the website of the National Institute of Statistics are time series and therefore for their processing several steps were followed:

1. False regression testing;

2. Stationary non-stationary series;

3. Estimation of the regression equation between stationary series;

4. Testing the hypotheses of the simple regression model;

5. Writing the regression equation and interpreting the coefficients;

6. Establishing the influence of the independent variable on the dependent variables.

The variables used in the research are presented in the following table. 
ToSEE - Tourism in Southern and Eastern Europe, Vol. 6, pp. 467-478, 2021. C-N. Mirea, P. Nistoreanu: EXISTING ACCOMMODATION CAPACITY, FACTOR OF INFLUENCE ...

Table 1: The variables

\begin{tabular}{ccrcc}
\hline Years & $\begin{array}{c}\text { Existing accommodation } \\
\text { capacity (places) }\end{array}$ & $\begin{array}{c}\text { Number of } \\
\text { tourists }\end{array}$ & $\begin{array}{c}\text { Number of } \\
\text { nights }\end{array}$ & $\begin{array}{c}\text { The average stay } \\
\text { (days) }\end{array}$ \\
\hline 2000 & 359 & 10112 & 29442 & 2.91 \\
2001 & 399 & 5105 & 18659 & 3.66 \\
2002 & 428 & 7592 & 25753 & 3.39 \\
2003 & 533 & 7427 & 35700 & 4.81 \\
2004 & 566 & 9456 & 37451 & 3.96 \\
2005 & 546 & 11714 & 52927 & 4.52 \\
2006 & 541 & 14157 & 83023 & 5.86 \\
2007 & 553 & 13927 & 52120 & 3.74 \\
2008 & 527 & 15946 & 53191 & 3.34 \\
2009 & 463 & 10215 & 27045 & 2.65 \\
2010 & 534 & 10600 & 27570 & 2.60 \\
2011 & 561 & 10657 & 33623 & 3.16 \\
2012 & 612 & 11929 & 31650 & 2.65 \\
2013 & 643 & 11035 & 34313 & 3.11 \\
2014 & 843 & 15857 & 35495 & 2.24 \\
2015 & 843 & 17809 & 36975 & 2.08 \\
2016 & 868 & 19095 & 38336 & 2.01 \\
2017 & 885 & 22090 & 51810 & 2.35 \\
2018 & 885 & 22357 & 54664 & 2.45 \\
2019 & 894 & 27472 & 66986 & 2.44 \\
\hline
\end{tabular}

Source: National Institute of Statistics (http://statistici.insse.ro/shop/, tempo online, accessed February 5, 2021)

\section{RESULTS}

Based on Table 1, it is observed that, during the analyzed period, the mentioned variables have an oscillating evolution. The existing accommodation capacity, the number of tourists and the number of overnight stays register a slightly increasing trend, while the average stay registers a slightly decreasing trend, but with increasing tendencies in the last years of the analyzed period. The slightly increasing trend of the number of tourists and the existing accommodation capacity may also be due to the increase of the average total monthly income per household during the analyzed period at national level, as following the calculation of the correlation coefficient, using excel, between the average total monthly income and the number of tourists arriving in Calarasi County, respectively, the existing accommodation capacity in Calarasi County and the average total monthly incomes per household were obtained strong correlations. The slight upward trend in the last years of the average stay may be due to a faster increase in the number of overnight stays and a slower increase in the number of tourists.

\subsection{Number of tourists arriving in Calarasi County and existing accommodation capacity}

The first stage consisted in analyzing the influence of the existing accommodation capacity on the number of tourists arriving in Calarasi County. Applying the regression 
ToSEE - Tourism in Southern and Eastern Europe, Vol. 6, pp. 467-478, 2021.

C-N. Mirea, P. Nistoreanu: EXISTING ACCOMMODATION CAPACITY, FACTOR OF INFLUENCE ...

between the two variables, with the help of the computer program Eviews, were obtained the following results.

Table 2: False regression testing

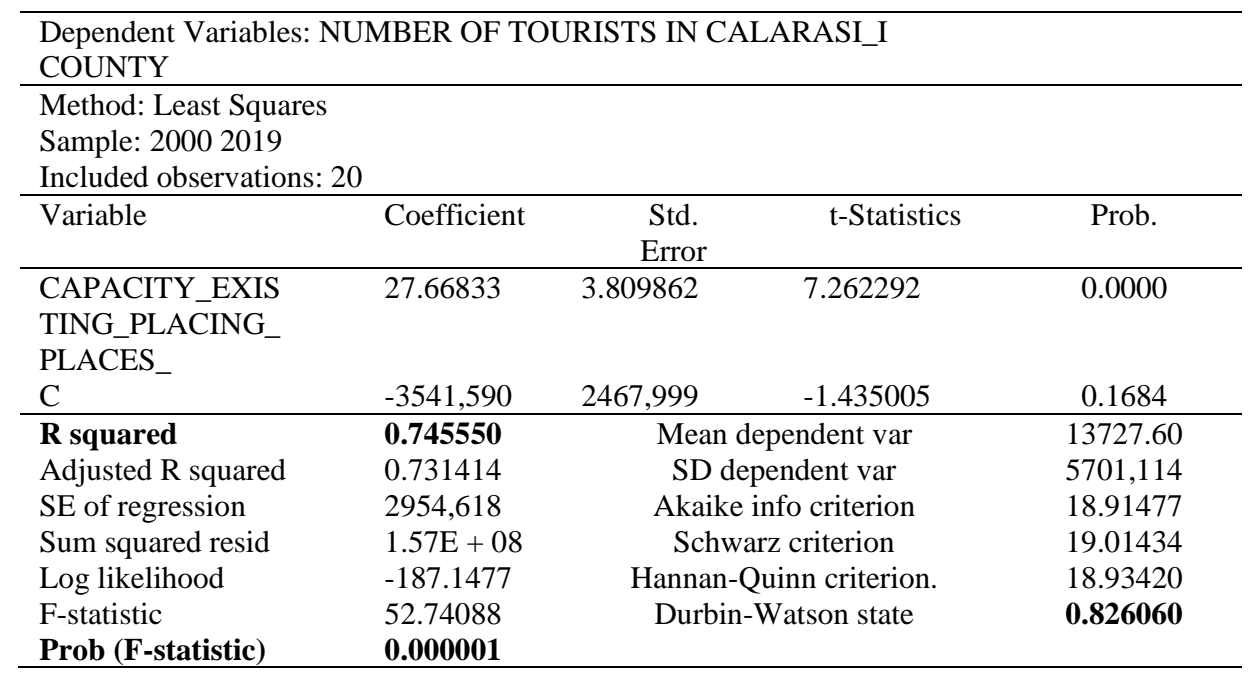

Source: data processed by the authors in Eviews

Taking into account the fact that the coefficient of determination (Rsquared) is lower than the statistics of the Durbin Watson test, it can be admitted that the regression between the number of tourists arriving in Calarasi County and the existing accommodation capacity is not false. Also, due to the fact that the probability of the $\mathrm{F}$ test is less than the significance threshold of $5 \%$, it can be assumed that the regression model is valid. Thus, the regression model between the number of tourists arriving in Calarasi County and the existing accommodation capacity is of the form:

$Y=a+b x t+e i$, where $a$ and $b$ are the model coefficients, $Y$ is the dependent variable, $t$ is the independent variable, and $e_{i}$ represent the model errors.

Applying the regression between the residual variable and the residual variable with a lag behind, it was obtained that it is correlated with itself. This indicates that the data series may not be stationary. The Augumented Dickey-Fuller (ADF) statistical test was applied to determine whether the analyzed data series are stationary. Thus, it was obtained that the data series - the existing accommodation capacity - is a stationary series as such, and the data series - the number of tourists arriving in Calarasi County- is a stationary series for the first difference. Estimating the regression equation between the stationary series - the existing accommodation capacity - and the stationary series for the first difference - the number of tourists arriving in Calarasi county - were obtained the following results. 
ToSEE - Tourism in Southern and Eastern Europe, Vol. 6, pp. 467-478, 2021.

C-N. Mirea, P. Nistoreanu: EXISTING ACCOMMODATION CAPACITY, FACTOR OF INFLUENCE ...

Table 3: Estimation of the regression equation between stationary series

\begin{tabular}{|c|c|c|c|c|}
\hline \multicolumn{5}{|c|}{$\begin{array}{l}\text { Dependent Variables: NUMBER OF TOURISTS IN CALARASI_I } \\
\text { COUNTY }\end{array}$} \\
\hline \multicolumn{5}{|c|}{$\begin{array}{l}\text { Method: Least Squares } \\
\text { Sample: } 20002019 \\
\text { Included observations: } 19 \text { after adjustments }\end{array}$} \\
\hline Variable & Coefficient & $\begin{array}{l}\text { Std. } \\
\text { Error }\end{array}$ & t-Statistics & Prob. \\
\hline $\begin{array}{l}\text { CAPACITY_EXIS } \\
\text { TING_PLACING_ } \\
\text { PLACES_ }\end{array}$ & 8.750278 & 3.232420 & 2.707036 & 0.0150 \\
\hline $\mathrm{C}$ & $-4669,914$ & 2131,774 & -2.190623 & 0.0427 \\
\hline R squared & 0.301218 & \multicolumn{2}{|c|}{ Mean dependent var } & 913,642 \\
\hline Adjusted nR squared & 0.260113 & \multicolumn{2}{|c|}{ SD dependent var } & 2729.135 \\
\hline SE of regression & 2347.511 & \multicolumn{2}{|c|}{ Akaike info criterion } & 18.45940 \\
\hline Sum squared resid & 93683731 & \multicolumn{2}{|c|}{ Schwarz criterion } & 18.55881 \\
\hline Log likelihood & -173.3643 & \multirow{2}{*}{\multicolumn{2}{|c|}{$\begin{array}{l}\text { Hannan-Quinn criterion. } \\
\text { Durbin-Watson state }\end{array}$}} & 18.47622 \\
\hline F-statistic & 7.328045 & & & 2.444132 \\
\hline Prob (F-statistic) & 0.014954 & & & \\
\hline
\end{tabular}

Source: data processed by the authors in Eviews

Given that Rsquared (coefficient of determination) is lower than the Durbin Watson test statistic, it can be admitted that the regression between the stationary series is not false. The $\mathrm{F}$ test statistic also indicates that the regression model between the stationary data series is statistically valid. Thus, the model can be written in the following form: Number of tourists arriving in Calarasi county $=-\mathbf{4 6 6 9 . 9 1}+\mathbf{8 . 7 5} \mathrm{x}$ existing accommodation capacity $+\mathbf{e}_{\mathrm{i}}$

The model being statistically valid, the hypotheses of the simple regression model were tested. Applying the White statistical test to test the heteroskedasticity hypothesis, the null hypothesis was accepted, ie the errors are homoskedastic. As the null hypothesis is accepted, the regression model does not need to be corrected.

Table 4: Heteroscedasticity hypothesis

\begin{tabular}{llll}
\hline \multicolumn{4}{l}{ Heteroskedasticity Test: White } \\
Null hypothesis: Homoskedasticity & & \\
\hline F-statistic & 2.035540 & Prob. F (1.17) & $\mathbf{0 . 1 7 1 8}$ \\
Obs * R-squared & 2.031739 & Prob. Chi-Square (1) & $\mathbf{0 . 1 5 4 0}$ \\
Scaled explained SS & 1.354358 & Prob. Chi-Square (1) & $\mathbf{0 . 2 4 4 5}$ \\
\hline
\end{tabular}

Source: data processed by the authors in Eviews

The Breusch-Godfrey statistical test was applied to test the hypothesis of lack of autocorrelation of errors. Following the application of this statistical test, the null hypothesis was accepted, ie the errors are not self-correlated. Thus, the model does not need to be corrected. 
ToSEE - Tourism in Southern and Eastern Europe, Vol. 6, pp. 467-478, 2021.

C-N. Mirea, P. Nistoreanu: EXISTING ACCOMMODATION CAPACITY, FACTOR OF INFLUENCE ...

Table 5: Hypothesis of lack of autocorrelation of errors

\begin{tabular}{|c|c|c|c|}
\hline \multicolumn{4}{|c|}{$\begin{array}{l}\text { Breusch-Godfrey Serial Correlation LM Test: } \\
\text { Null hypothesis: No serial correlation at up to } 2 \text { lags }\end{array}$} \\
\hline F-statistic & 1.195825 & Prob. F (2.15) & 0.3297 \\
\hline Obs $* \mathrm{R}$-squared & 2.612825 & Prob. Chi-Square (2) & 0.2708 \\
\hline
\end{tabular}

Source: data processed by the authors in Eviews

The last hypothesis tested was the normal error distribution. The Jarque-Bera statistical test was used to test this hypothesis. Following the application of the test, the null hypothesis was accepted, according to which the errors are normally distributed. In this sense, the regression model does not need to be corrected.

\section{Graph 1: Hypothesis of normality of error distribution}

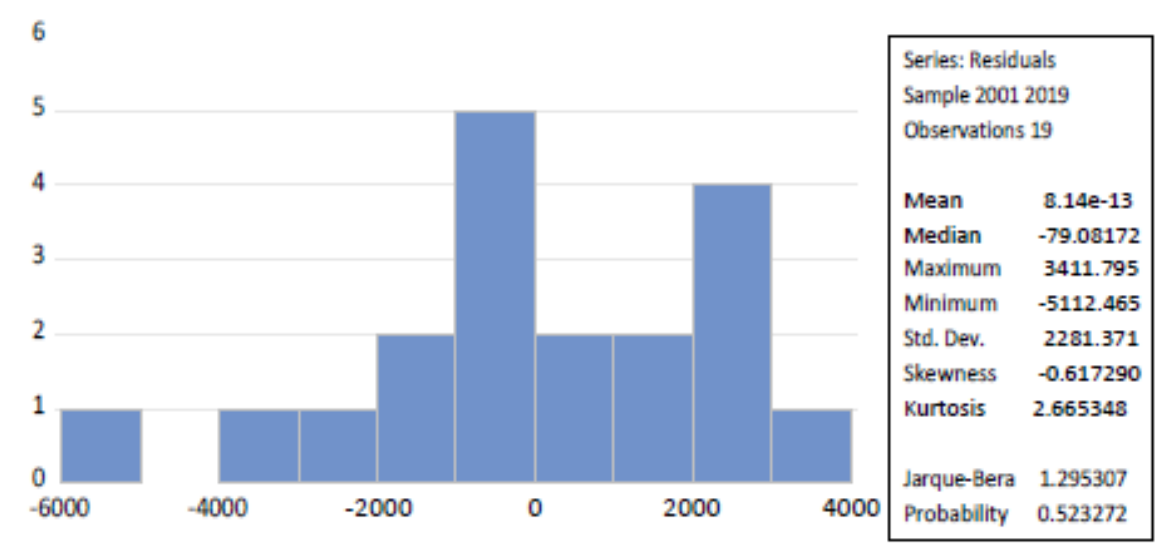

Source: data processed by the authors in Eviews

Due to the fact that the probabilities of the statistical test $t$, related to the model coefficients, presented in table 3 are less than $5 \%$, it results that the model coefficients are statistically significant. Thus, the regression model Number of tourists arriving in Calarasi County $=-4669.91+8.75 \mathrm{x}$ existing accommodation capacity $+e_{i}$ it is statistically valid, and the interpretation of the coefficients is as follows: with an increase of one place in the existing accommodation capacity, the number of tourists will increase by 8.75 tourists. Also, the value of the coefficient of determination (Rsquared) presented in table 3 is 0.30 , which means that $30 \%$ of the variation in the number of tourists is explained by the model. In other words, $30 \%$ represents the influence of the existing accommodation capacity on the number of tourists from Calarasi County. 
ToSEE - Tourism in Southern and Eastern Europe, Vol. 6, pp. 467-478, 2021.

C-N. Mirea, P. Nistoreanu: EXISTING ACCOMMODATION CAPACITY, FACTOR OF INFLUENCE ...

\subsection{Number of overnight stays and existing accommodation capacity}

The second stage consisted in analyzing the influence of the existing accommodation capacity on the number of overnight stays. Applying the regression between the two variables, a statistically invalid model was obtained for the first time. Although Rsquared was lower than the Durbin Watson test statistic, the probability of the $F$ test was greater than $5 \%$, which means that the model expressed by the regression equation is not statistically valid. Thus, for the period $2000-2019$, it is not possible to measure the influence of accommodation capacity on the number of overnight stays with the regression. Therefore, using the Excel calculation program, the Pearson correlation coefficient was calculated between the existing accommodation capacity and the number of overnight stays, obtaining the data from the following table:

Table 6: Correlation between existing accommodation capacity and number of overnight stays

\begin{tabular}{lcc}
\hline & Existing accommodation capacity & Number of nights \\
\hline Existing accommodation capacity & 1 & \\
\hline Number of nights & $\mathbf{0 . 3 7}$ & 1 \\
\hline
\end{tabular}

Source: data processed by authors in Excel

The value 0.37 is in fact the Pearson correlation coefficient and indicates a weak link / correlation between accommodation capacity and number of nights. In this respect, the influence of accommodation capacity on the number of overnight stays can be considered weak. In terms of probability, in the following years there is a $20 \%$ chance that the number of overnight stays in Calarasi County will decrease and there is an $80 \%$ chance that it will increase. The high chances of increasing the number of overnight stays may also be due to the fact that Calarasi County benefits from an increased accessibility, due to the presence of the highway Autostrada Soarelui, which connects the capital Bucharest and the Black Sea coast. Also, another strong point that could contribute to the increase of the number of overnight stays would be the fact that Calarasi County is a border county, being the gateway to Bulgaria.

\subsection{Average stay and existing accommodation capacity}

The third stage consisted in analyzing the influence of the existing accommodation capacity on the average stay. After the first application of the regression, the probability of the $F$ test was less than 5\%, which indicated that the model is valid. Also, the value of Rsquared was less than the value of the Durbin Watson test, which meant that the regression was not false. The existing accommodation capacity was a stationary series as such, and the average stay series was stationary at the first difference. After applying the regression to the two stationary data series, the regression model was not statistically valid. More specifically, the influence of the existing accommodation capacity on the average stay, in the period 2000-2019, cannot be estimated using regression. Using the Excel calculation program, the correlation between the existing accommodation capacity and the average stay was made, obtaining the data from the following table. 
ToSEE - Tourism in Southern and Eastern Europe, Vol. 6, pp. 467-478, 2021. C-N. Mirea, P. Nistoreanu: EXISTING ACCOMMODATION CAPACITY, FACTOR OF INFLUENCE ...

Table 7: Correlation between existing accommodation capacity and average stay

\begin{tabular}{lcc}
\hline & Existing accommodation capacity & The average stay \\
\hline Existing accommodation capacity & 1 & \\
\hline The average stay & $\mathbf{- 0 . 5 4}$ & 1 \\
\hline
\end{tabular}

Source: data processed by authors in Excel

The value -0.54 represents the Pearson correlation coefficient and indicates a moderate negative link / correlation between accommodation capacity and average stay. In terms of probability, in the following years there is a 55\% chance that the average stay will decrease and a $45 \%$ chance will increase. The chances of decreasing the stay can be based on the fact that after calculating the correlation coefficient between the average stay in Calarasi County and the level of average monthly total household income at national level, a moderate negative correlation was obtained. In other words, if the income of a romanian tourist increases, the chances for that tourist to visit Calarasi County are relatively small. In this regard, tourism service providers and local authorities need to focus on the needs of tourists, so that Calarasi County can become competitive from a tourist point of view. Moreover, from an economic point of view, it would be essential for the number of accommodation to be directly proportional to the average stay, as it would stimulate the need for labor. According to the National Institute of Statistics (http://statistici.insse.ro/shop/ accessed February 5, 2021), in 2019, the number of employees in the field of hotels and restaurants in Calarasi County was 1038 employees. Following the calculation of the Pearson correlation coefficient between accommodation capacity and the number of employees in the field of hotels and restaurants, using Excel, in the period 2000-2019 for Calarasi County, showed that there is a strong direct correlation between the two variables, the coefficient having the value of 0.80 . In other words, by increasing the accommodation capacity, new jobs would be created, which could lead to the increase of the living standard of the county's citizens.

\section{CONCLUSION}

The importance of accommodation capacity is indisputable for any area with tourist potential, and Calarasi County has an extraordinary tourist potential, given the fact that the county's territory is crossed by the Danube River. The capitalization of the tourist potential cannot be achieved without the existence of accommodation capacities. Thus, local authorities should support existing accommodation structures and contribute to the creation of new ones, because when increasing with one accommodation, the number of tourists will increase by about 9 tourists, according to the results. Also, with a possible increase in accommodation capacity, new jobs could appear. More, the moderate influence of $30 \%$ of the existing accommodation capacity on the number of tourists suggests that there are other variables that underline the motivation of tourists to visit Calarasi County. In this regard, local tourism stakeholders should focus on promotion campaigns and the provision of unique experiences. Also, the weak link between the number of overnight stays and the existing accommodation capacity suggests that an increase in the number of accommodation places does not generate an increase in the number of overnight stays. Rather, an increase in the number of overnight stays may be 
ToSEE - Tourism in Southern and Eastern Europe, Vol. 6, pp. 467-478, 2021.

C-N. Mirea, P. Nistoreanu: EXISTING ACCOMMODATION CAPACITY, FACTOR OF INFLUENCE ...

generated by the hospitality of the hosts and the quality of services provided inside the accommodation units. It should be noted that in terms of probability, the number of overnight stays in Calarasi County has very high chances to increase in the coming years. Regarding the correlation coefficient obtained between the existing accommodation capacity and the average stay, we can say that the stay is not affected by the variation of the number of accommodation places. Based on the results obtained, we consider that the relatively small number of tourists compared to the tourist potential of the county is not generated by the variation of existing accommodation, so the existing accommodation capacity is a moderate influence on tourist arrivals in Calarasi County during the analyzed period. Thus, in order to consolidate the results, we consider that it is auspicious that in the future primary data sources will be used. More precisely, collecting the opinions of the tourists arriving in the accommodation units from Calarasi County regarding the quality of the accommodation service. Also, a major importance would have the inventory of tourist services offered by accommodation units in the county, because we believe that existing accommodation capacity can become a major factor influencing the number of tourists only if accommodation units are not limited to accommodation services and food services. Thus, a solution for the existing accommodation capacity to become a major influencing factor on the number of tourists would be for the accommodation units to offer tourists a wide range of additional services and activities.

\section{REFERENCES}

Anguera-Torrell, O. and Cerdan, A. (2021), "Which commercial sectors coagglomerate with the accommodation industry? Evidence from Barcelona", Cities, Vol. 112, pp. 1-15. https://doi.org/10.1016/j.cities.2021.103112

Bawa, M.I. (2017), "Relationship between Tourist Arrival and Accommodation Capacity: Statistical Perspective From Sri Lanka", International Journal of Commerce, Management and Computer Application, Vol. 3, No.1, pp. 15-18.

Calarasi County Council (n.d.), Tourism, viewed 22 February 2021, https://www.calarasi.ro/index.php/judetulcalarasi-meniu-stanga/turism

Cristache, S.E. (2008), Statistical methods with applications in tourism management, ASE Publishing House, Bucharest.

Cruz, M.S. and Zaragoza, M.P. (2019), "Analysis of the Accommodation Density in Coastal Tourism Areas of Insular Destinations from the Perspective of Overtourism", Sustainability, Vol. 11, No. 11, pp. 119. https://doi.org/10.3390/su11113031

Gheorghe, A. (2015), "The influence of the number of overnight stays on the capacity of the accommodation in Salaj County", Knowledge Horizons - Economics, Vol. 7, No. 3, pp. 147-150.

Lakicevic, M. and Sagic, Z. (2019), "Accommodation capacities and their utilization in the function of tourism development: case of Ivanjica", Ekonomika, Vol. 65, No. 3, pp. 77-88.

Maican, S. Cordos, M. Pastiu, C. and Muntean, A. (2014), "Study regarding the evolution of tourist accommodation facilities - the case of Alba County, Romania", Biennial International Congress. Tourism and Hospitality Industry, Opatija: Faculty of Tourism and Hospitality Management, pp. 584-600.

Mărculeț, I. (2019), Romanian Counties. Geographic Encyclopedia, "IL Caragiale" National College, Bucharest.

Medina-Munoz, D. Medina-Munoz, R. and Sanchez-Medina, A. (2016), "Renovation strategies for accommodation at mature destinations: A tourist demand-based approach", International Journal of Hospitality Management, Vol. 54, pp. 127-138.

Minciu, R. (2004), Economics of Tourism, Uranus Publishing House, Bucharest.

National Institute of Statistics (2018), Indicators of Territorial Sustainable Development in Romania, viewed 18 February 2021, https://insse.ro/cms/files/IDDT2012/index_IDDT.htm. 
ToSEE - Tourism in Southern and Eastern Europe, Vol. 6, pp. 467-478, 2021.

C-N. Mirea, P. Nistoreanu: EXISTING ACCOMMODATION CAPACITY, FACTOR OF INFLUENCE ...

National Institute of Statistics (n.d.), INSSE - Statistical databases - TEMPO - Online time series, viewed 5 February 2021, http://statistici.insse.ro/shop/

Petrevska, B. (2012), "Projecting accommodation capacities in Macedonia", Procedia - Social and Behavioral Sciences, pp. 88-94.

Pop, I. Popescu, C.R. Holostencu, L.F. and Popescu, D. (2020), "Basic tourism concepts in Romania", BASIQ International Conference on New Trends in Sustainable Business and Consumption, ASE București, Messina, pp. 548-555.

Săgeată, R. (2013), The territorial administrative organization of Romania. Evolution. Optimization Proposals, viewed 22 February 222021

https://d1wqtxts1xzle7.cloudfront.net/37943693/Organizzazione_administrativteritoriala_a_Romanie i..pdf?1 434704143=\&response-contentdisposition=inline $\% 3 \mathrm{~B}+$ filename $\% 3$ DOrganizzazione_adw\&Sa

Sava, C. (2013), "The evolution of regional accommodation capacity - case study West Development Region", Knowledge Horizons. Economics, București: Dimitrie Cantemir Christian University, Vol. 5, No. 2, pp. 82-86.

Skoric, S. (2012), "Planning the level of accommodation capacities in winter sport destinations", An Enterprise Odyssey. International Conference Proceedings, Zagreb: Faculty of Economics and Business, pp. 1356-1364.

Țigu, G. Călărețu, B. V. and Bulin, D. (2013), "Tourism Destination Management - New Approaches in Romania", International Journal of Academic Research in Business and Social Sciences, Vol.3, No. 7, pp. 720-738. http://dx.doi.org/10.6007/IJARBSS/v3-i7/103

Virgil, N. and Neagu, R.E. (2013), "Evolution of Tourist Accommodation Structures in Romanian's Developing Regions in the Context of New Challenges at European Level", Procedia Economics and Finance, Vol. 6, pp. 542-549

Cosmin-Nicolae Mirea, Doctoral Student

Bucharest University of Economic Studies, Romana Square 6, Bucharest, Romania +40734867486

cosminnicolaemirea@gmail.com

Puiu Nistoreanu, PhD, Full Professor Bucharest University of Economic Studies, Department of Tourism and Geography Romana Square 6, Bucharest, Romania +40744791891

puiu.nistoreanu@com.ase.ro 